\title{
Regulation of Catalase in Neisseria gonorrhoeae Effects of Oxidant Stress and Exposure to Human Neutrophils
}

He-yi Zheng, Daniel J. Hassett, Karen Bean, and Myron S. Cohen

Departments of Medicine, Microbiology, and Immunology, University of North Carolina,

School of Medicine, Chapel Hill, North Carolina 27599

\begin{abstract}
We studied the effects of oxidant stress on the catalase activity and hydrogen peroxide sensitivity of Neisseria gonorrhoeae. $N$. gonorrhoeae is an obligate pathogen of man that evokes a remarkable but ineffective neutrophil response. Gonococci make no superoxide dismutase but express high catalase activity. Gonococcal catalase activity increased threefold when organisms were subjected to $1.0 \mathrm{mM}$ hydrogen peroxide. This increase in catalase activity was marked by a parallel increase in protein concentration recognized by a rabbit polyclonal antibody raised against the purified gonococcal enzyme. Catalase was primarily localized to the gonococcal cytoplasm in the presence or absence of stress; only a single isoenzyme of catalase could be identified. Exposure of gonococci to neutrophil-derived oxidants was accomplished by stimulating neutrophils with phorbol myristate acetate or by using gonococcal Opa variants that interacted with neutrophils with different degrees of efficiency. Gonococci exposed to neutrophils demonstrated a twofold increase in catalase activity in spite of some reduction in viability. Exposure of gonococci to $1.0 \mathrm{mM}$ hydrogen peroxide made the organisms significantly more resistant to higher concentrations of hydrogen peroxide and to neutrophils than control organisms. These results suggest that catalase is an important defense for $\boldsymbol{N}$. gonorrhoeae during attack by human neutrophils. The rapid response of this enzyme to hydrogen peroxide should be taken into consideration in studies designed to evaluate the interaction between neutrophils and gonococci. (J. Clin. Invest. 1992. 90:1000-1006.) Key words: Neisseria gonorrhoeae $\bullet$ catalase $\bullet$ neutrophils $\bullet$ hydrogen peroxide
\end{abstract}

\section{Introduction}

Neisseria gonorrhoeae is an obligate pathogen of man primarily confined to mucous membranes (1). Most strains of this organism evoke a remarkable neutrophilic exudate (2). However, this organism can be recovered from inflammatory foci without difficulty, suggesting a variety of adaptive mechanisms

This work was presented in part in abstract form (Abstract No. 282) at the 31 st Interscience Conference on Antimicrobial Agents and Chemotherapy, 29 September-2 October 1991, Chicago, IL.

Address correspondence to Myron S. Cohen, M. D., Department of Medicine, Division of Infectious Diseases, University of North Carolina School of Medicine, 547 Burnett-Womack, CB No. 7030, Chapel Hill, NC 27599-7030.

Received for publication 21 October 1991 and in revised form 30 March 1992.

J. Clin. Invest.

(C) The American Society for Clinical Investigation, Inc.

0021-9738/92/09/1000/07 \$2.00

Volume 90, September 1992, 1000-1006 that allow bacterial survival even after phagocytosis (3). Several mechanisms of resistance have been examined. These include failure of the organism to express surface components required for maximal formation of chemotactic complement components (2), lack of expression of surface components that facilitate attachment to phagocytes $(4,5)$, expression of antiphagocytic factors (6), and/or other mechanisms of resistance (7, for review see reference 8 ).

Professional phagocytes use a combination of mechanisms to kill bacterial pathogens. These are generally divided into mechanisms that require the use of molecular oxygen for the formation of free radicals (9) and/or those that depend on microbicidal proteins that can work under anaerobic conditions (10). In vivo, these mechanisms almost certainly work in concert.

Phagocytic cells possess a unique NADPH oxidase system that allows the transfer of a single electron to molecular oxygen resulting in the formation of superoxide (11). Superoxide is dismutated to hydrogen peroxide $\left(\mathrm{H}_{2} \mathrm{O}_{2}\right)$ and may lead to the generation of more toxic reactive oxygen intermediates such as hypochlorous acid $(\mathrm{HOCl})$ and/or hydroxyl radical $\left(\mathrm{HO}^{\circ}\right)$ under appropriate conditions of incubation (9). To survive reactive oxygen intermediates, microbes possess a variety of antioxidant defenses, including superoxide dismutase (which eliminates superoxide) and catalase (which detoxifies $\mathrm{H}_{2} \mathrm{O}_{2}$ ). A correlation between survival of microbial pathogens and the level of antioxidant defenses has been reported (for review see reference 12).

$N$. gonorrhoeae is unique relative to most aerobic organisms because it does not produce superoxide dismutase (1315). However, gonococci generate catalase in high concentration $(14,16)$. The current study was undertaken to examine the response of gonococci to $\mathrm{H}_{2} \mathrm{O}_{2}$ and polymorphonuclear neutrophils. The results demonstrate that expression of catalase is dynamic and increases during exposure of these organisms to neutrophil attack. Increase in gonococcal catalase activity provides protection from exogenous $\mathrm{H}_{2} \mathrm{O}_{2}$ and from human neutrophils.

\section{Methods}

Reagents. Chloramphenicol, $\mathrm{H}_{2} \mathrm{O}_{2}$, bovine erythrocyte $\mathrm{SOD}$, bovine liver catalase, paraquat, desferrioxamine mesylate (Desferal), phorbol myristate acetate (PMA), and TCA were purchased from Sigma Chemical Co. (St. Louis, MO).

Growth of gonococci and generation of subcellular fractions. N. gonorrhoeae strain FA1090, a clinical isolate provided by P. Frederick Sparling (University of North Carolina at Chapel Hill), was subcultured daily on $0.18 \%$ (wt/vol) Bacto agar and 3.6\% GC Medium Base (Difco Laboratories Inc., Detroit, MI) that contained 1 and $0.1 \%$ (vol/ vol) Kellogg supplements I and II, respectively (16). Broth cultures were obtained by inoculating a single colony into proteose peptone GCB broth containing $2 \%$ supplement I and $5 \mathrm{mM}$ sodium bicarbon- 
ate; bacteria were grown to mid-log phase on a platform shaker at 140 cycles $/ \mathrm{min}, 37^{\circ} \mathrm{C}$, in an atmosphere of $5 \% \mathrm{CO}_{2}$. Cell density was monitored with a spectrophotometer (DMS-80; Varian Associates Inc., Palo Alto, CA ). A reading of OD 0.5 at $600 \mathrm{~nm}$ indicated the presence of $\sim 2.5 \times 10^{8} \mathrm{CFU} / \mathrm{ml}$. Bacteria were pelleted by centrifugation and resuspended in ice-cold $50 \mathrm{mM}$ Tris- $\mathrm{HCl}, \mathrm{pH}$ 8.0. To generate preparations representing different cellular compartments $(17), 10^{9}$ gonococci were sonicated for $30 \mathrm{~s}$ at setting 60 in a sonic dismembrator (model 300; Fisher Scientific, Pittsburgh, PA) followed by cooling on ice for 30 $\mathrm{s}$; this was repeated three times. Cells were centrifuged $3,000 \mathrm{~g}$ for $5 \mathrm{~min}$ to remove debris. The supernatant represented the whole-cell extract. A portion of the whole-cell extract was subjected to further sonication and centrifuged at $100,000 \mathrm{~g}$ for $60 \mathrm{~min}$; the supernatant contained the cytoplasmic proteins. The pellet was resuspended in $10 \mathrm{mM}$ Hepes buffer, $1 \% \mathrm{Na}$-laurylsarcosine, $10 \mathrm{mM} \mathrm{MgCl}_{2}$, $\mathrm{pH} 7.4$ and sonicated as described above. This extract was centrifuged at $100,000 \mathrm{~g}$ for $60 \mathrm{~min}$; the supernatant contained the cytoplasmic membrane proteins. The pellet containing the outer membrane was resuspended in $100 \mu 1 \mathrm{H}_{2} \mathrm{O}$.

Preparation of neutrophils. Whole blood from normal human donors was obtained in heparinized syringes. Neutrophils were separated from erythrocytes by incubation of $25 \mathrm{ml}$ of whole blood with $10 \mathrm{ml}$ Plasmagel (Roger Belon, Neuilly, France) for $1 \mathrm{~h}$. Leukocyte populations were further separated on a Ficoll-Hypaque gradient as previously described (7). Contaminating erythrocytes were eliminated by osmotic lysis. Neutrophils were resuspended in cold HBSS and the concentration of cells determined by an automated cell counter (Coulter Electronics Inc., Hialeah, FL). Viability was assessed by trypan blue dye exclusion and was $>95 \%$.

Determination of catalase and glucose 6-phosphate dehydrogenase $(G-6 P D H)^{l}$ activity. Catalase activity was assayed on the basis of the decomposition of $\mathrm{H}_{2} \mathrm{O}_{2}$ monitored at $240 \mathrm{~nm}$ in a spectrophotometer as previously described (18). One unit of catalase activity was defined as the amount that decomposes $1 \mu \mathrm{mol}$ of $\mathrm{H}_{2} \mathrm{O}_{2} / \mathrm{min}$ at room temperature using $17.6 \mathrm{mM} \mathrm{H}_{2} \mathrm{O}_{2}$. The protein concentration in different cell fractions was measured by the method of Bradford (19). Proteins (2$10 \mu \mathrm{g}$ ) from different cellular compartments were separated by electrophoresis on $5 \%$ polyacrylamide gels. Before application of samples, materials for catalase native gels were electrophoresed in the presence of $0.1 \mathrm{mM}$ sodium thioglycollate to remove gel impurities that might cause multiple activity bands. Catalase was visualized with an activity stain as previously described (20). Subcellular fractions were also examined for G-6PDH activity, which was measured as previously described (21).

Determination of catalase protein concentration. Antibodies to gonococcal catalase were raised in a rabbit to use in Western blotting experiments. Gonococcal catalase was partially purified by column chromatography as previously described (14). Partially purified catalase was subjected to electrophoresis through a 5\% SDS-PAGE gel and was soaked overnight in $50 \mathrm{mM}$ potassium phosphate buffer, $\mathrm{pH}$ 7.4. A band with retained catalase activity was cut from the gel, subjected to three cycles of freeze-thawing, and passed through a 25-gauge needle. Gel fragments were then dissolved in an equal volume of Freund's complete adjuvant (Sigma Chemical Co). A rabbit was immunized with this preparation and was bled, as previously described (22).

To eliminate cross-reacting antibodies, rabbit serum was absorbed with a cytoplasmic preparation from a naturally occurring catalase-deficient mutant provide by Dr. Steven Johnson (Centers for Disease Control). Serum was diluted in PBS (1:10) and exposed to $50 \mu \mathrm{g}$ of this protein for $1 \mathrm{~h}$ at $37^{\circ} \mathrm{C}$, and for $16 \mathrm{~h}$ at $4^{\circ} \mathrm{C}$, as previously described (23). Immune (but not preimmune) serum reacted with a single protein band migrating at an identical speed as purified gonococcal catalase on an SDS-PAGE gel.

For immunoblotting experiments gonococcal cytoplasmic proteins were subjected to electrophoresis on a 5\% SDS-PAGE gel. Proteins

1. Abbreviation used in this paper: G-6PDH, glucose 6-phosphate dehydrogenase. were transferred to nitrocellulose (PUDF; Millipore Corporation, Bedford, MA) using the Western blotting technique of Burnette (24). After transfer, nitrocellulose was incubated in 5\% dried milk in PBS for $1 \mathrm{~h}$ and washed with PBS for $15 \mathrm{~min}$. Nitrocellulose was then incubated with a 1:1200 dilution of rabbit serum in PBS at room temperature for $1 \mathrm{~h}$. Nitrocellulose was washed for $30 \mathrm{~min}$ with PBS and incubated with horseradish peroxidase-conjugated goat anti-rabbit IgG (BRL Life Technologies, Inc., Gaithersburg, MD) diluted 1:3000 in PBS. Nitrocellulose was washed for $30 \mathrm{~min}$ and antibody reactions were detected after $1 \mathrm{~min}$ using the enhanced chemiluminescence technique (Amersham International, Arlington Heights, IL; reference 25). The nitrocellulose was covered, exposed to hyperfilm-TMP (Amersham International) for 1-3 min, and developed in a Kodak D19 Developer. Using this procedure immune (but not preimmune) rabbit serum identified a protein that migrated at exactly the same speed as gonococcal catalase activity recognized on SDS-PAGE gel (see Fig. 4). The immune rabbit serum did not react with cytoplasmic proteins of similar size from the catalase deficient gonococcal isolate or several Escherichia coli strains.

Bacterial exposure to $\mathrm{H}_{2} \mathrm{O}_{2}$ and neutrophils. $\mathrm{H}_{2} \mathrm{O}_{2}$ stress of gonococci was undertaken by exposing log-phase bacteria to $0.3-1.0 \mathrm{mM}$ $\mathrm{H}_{2} \mathrm{O}_{2}$ at 10 -min intervals for $1 \mathrm{~h}$ at $37^{\circ} \mathrm{C}$ with shaking ( 140 cycles/ min) in GC broth. In some experiments exposure of bacteria to $\mathrm{H}_{2} \mathrm{O}_{2}$ was compared with alternative forms of stress. Heat shock was achieved by incubating log-phase gonococci at $42^{\circ} \mathrm{C}$ for $1 \mathrm{~h}$ (17). To examine the effects of intracellular superoxide, gonococci were treated with $1.0 \mathrm{mM}$ paraquat for $1 \mathrm{~h}$ at $37^{\circ} \mathrm{C}(26)$. For experiments with neutrophils, $1.5-2.5 \times 10^{7}$ gonococci and neutrophils (1:1 particle/cell ratio) were incubated for $120 \mathrm{~min}$ at $37^{\circ} \mathrm{C}$ with shaking ( 140 cycles/ min) in a $5 \% \mathrm{CO}_{2}$ atmosphere. The neutrophils were then lysed by sonication ( $20 \mathrm{~s}$, setting 60 ). This magnitude of sonication did not reduce gonococcal viability. Gonococci were centrifuged $(800 \mathrm{~g})$ and washed three times with cold PBS to eliminate contaminating neutrophils. The number of surviving gonococci was determined based on growth on GCB agar after $48 \mathrm{~h}$ of incubation at $37^{\circ} \mathrm{C}$. This assay measures total gonococcal killing and does not separate intracellular and extracellular killing by neutrophils. In some experiments new protein synthesis was inhibited by treating gonococci with chloramphenicol $(100 \mu \mathrm{g} / \mathrm{ml})$ for $1 \mathrm{~h}$ at $37^{\circ} \mathrm{C}$.

\section{Results}

Effects of $\mathrm{H}_{2} \mathrm{O}_{2}$ on gonococcal catalase. Gonococci were exposed to increasing concentrations of exogenous $\mathrm{H}_{2} \mathrm{O}_{2}$ to examine the effects of such stress on catalase activity. An increase in gonococcal catalase activity was observed when organisms were exposed to as little as $0.3 \mathrm{mM} \mathrm{H}_{2} \mathrm{O}_{2}$ for $40 \mathrm{~min}$. Maximal effects on catalase were observed when $1.0 \mathrm{mM} \mathrm{H}_{2} \mathrm{O}_{2}$ was employed. Treatment of $10^{9}$ log-phase gonococci with six pulses of $1 \mathrm{mM} \mathrm{H} \mathrm{H}_{2} \mathrm{O}_{2}$ over 60 min caused a threefold increase in catalase activity (Fig. 1). This concentration of $\mathrm{H}_{2} \mathrm{O}_{2}$ caused limited reduction in viability (see Fig. 7).

To determine whether other forms of stress could affect catalase activity, gonococci were also exposed to sublethal concentrations of the superoxide-generating compound paraquat (26) and heat shock $(17,27)$. Heat shock did not increase catalase activity; paraquat reduced catalase activity (Fig. 1).

Gonococcal catalase was also characterized by native gel electrophoresis (Fig. 2). Gonococci were subjected to subcellular fractionation to examine compartmentalization of catalase (Fig. 2). The increase in catalase observed after exposure of the organisms to $\mathrm{H}_{2} \mathrm{O}_{2}$ was restricted primarily to the bacterial cytoplasm (Fig. 2, Table I). $0.9 \%$ of the total catalase activity was found in the cytoplasmic membrane preparation. To examine contamination of the cytoplasmic membrane preparation G-6PDH activity (a bacterial cytoplasmic enzyme) was mea- 


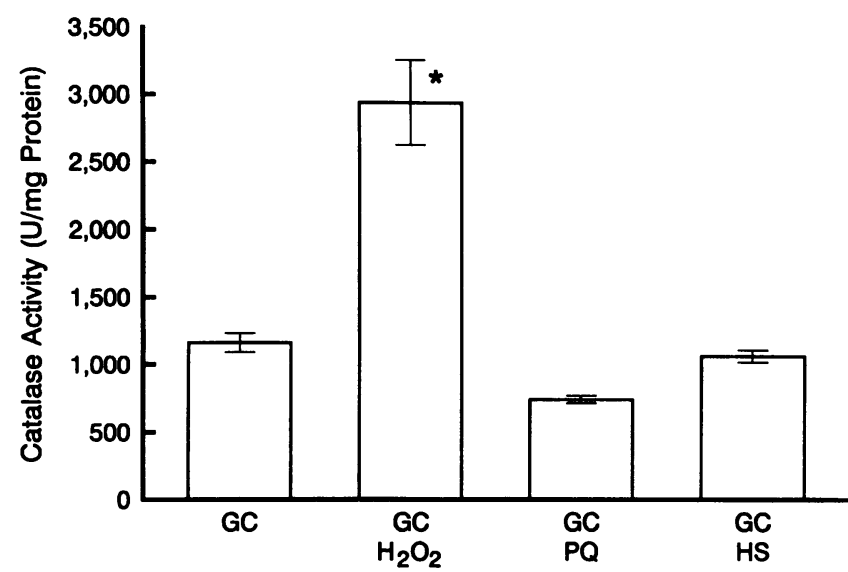

Figure 1. Response of gonococci to $\mathrm{H}_{2} \mathrm{O}_{2} \cdot 10^{9}$ log-phase gonococci were exposed six times to $1.0 \mathrm{mM} \mathrm{H}_{2} \mathrm{O}_{2}$ at 10 -min intervals and effect on catalase activity $(\mathrm{U} / \mathrm{mg}$ protein $)$ was examined. Gonococci were exposed to $1.0 \mathrm{mM}$ paraquat $(P Q)$ to generate $\mathrm{O}_{2^{-}}(26)$ and to heat shock $\left(H S, 42^{\circ} \mathrm{C}\right)$ for $1 \mathrm{~h}(17)$. Results are the mean and SEM of three to eight separate experiments, each in duplicate. ${ }^{*}$ Differences $(P<0.001)$ between control and treated bacteria.

sured (21). G-6PDH activity was detected only in the cytoplasmic compartment ( Table I). Using either native gel (Fig. 2) or SDS-PAGE (data not shown), a single broad band of catalase activity was observed before and after $\mathrm{H}_{2} \mathrm{O}_{2}$ stress and in the cytoplasmic and membrane fractions.

Mechanism(s) of increase in catalase activity. An increase in gonococcal catalase activity after exposure to $\mathrm{H}_{2} \mathrm{O}_{2}$ could be due to the formation of new protein or to an increase in the activity of preformed enzyme. To examine these possibilities $\mathrm{H}_{2} \mathrm{O}_{2}$-treated gonococci were exposed to a sublethal concentration of chloramphenicol, to block the new protein formation (28). In the presence of chloramphenicol, catalase activity was not increased during exposure to $\mathrm{H}_{2} \mathrm{O}_{2}$ (Fig. 3). To determine

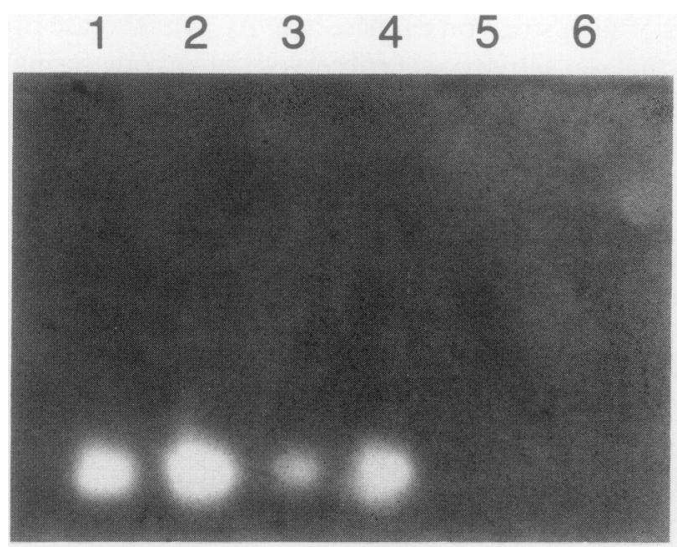

Figure 2. Examination of catalase activity by native electrophoresis gel. Gonococcal preparations were fractionated to generate cytoplasmic (lanes 1 and 2), cytoplasmic membrane (lanes 3 and 4), and outer membrane proteins (lanes 5 and 6 ). Lanes 1 and 2 were loaded with $2.0 \mu \mathrm{g}$ protein. Lanes 3-6 were loaded with $10 \mu \mathrm{g}$ protein. Some preparations of gonococci were exposed to $1.0 \mathrm{mM} \mathrm{H}_{2} \mathrm{O}_{2}$ (lanes 2, 4, and 6 ) as described in Fig. 1. Results are typical of 10 different experiments.
Table I. Distribution of Catalase and Glucose-6 Phosphate Dehydrogenase

\begin{tabular}{|c|c|c|c|}
\hline & \multicolumn{2}{|c|}{ Catalase } & \multirow[b]{2}{*}{ G-6PDH } \\
\hline & $-\mathrm{H}_{2} \mathrm{O}_{2}$ & $+\mathrm{H}_{2} \mathrm{O}_{2}$ & \\
\hline & \multicolumn{2}{|c|}{$U / m g$ protein } & $U / m g$ protein \\
\hline $\mathrm{CP}$ & $1,160.6 \pm 70.4$ & $2,941.7 \pm 313.0^{*}$ & 827.5 \\
\hline CMP & $10.2 \pm 01.9$ & $23.8 \pm 3.4^{*}$ & 0 \\
\hline OMP & 0 & 0 & 0 \\
\hline
\end{tabular}

Results for catalase activity are the mean and SEM of four separate experiments, each in duplicate. Results with G-6PDH are the mean of two experiments in duplicate. 98 and $96.7 \%$ of catalase and G-6PDH activity were recovered from whole cell extracts, respectively. CP, cytoplasm proteins; CMP, cytoplasm membrane proteins; OMP, outer membrane proteins. ${ }^{*}$ Significant differences $(P<0.01)$ between control gonococci and organisms treated with $1 \mathrm{mM} \mathrm{H}_{2} \mathrm{O}_{2}$.

whether availability of iron affected gonococcal catalase expression, the iron chelator desferrioxamine was included during exposure of the organism to $\mathrm{H}_{2} \mathrm{O}_{2}$; desferrioxamine did not significantly inhibit the response of gonococci under these conditions (Fig. 3).

Inhibition by chloramphenicol of catalase activity expected in response to $\mathrm{H}_{2} \mathrm{O}_{2}$ strongly suggested that $\mathrm{H}_{2} \mathrm{O}_{2}$ stress resulted in new protein formation. To confirm this idea we took advantage of a polyclonal rabbit antibody raised to purified gonococcal catalase. Using this antibody, we demonstrated a two- to threefold increase in gonococcal catalase protein detectable by immunoblotting after exposure of gonococci to $1.0 \mathrm{mM} \mathrm{H}_{2} \mathrm{O}_{2}$ (Fig. 4).

Effects of human neutrophils on gonococcal catalase. The attack of gonococci by neutrophils is an event considerably more complicated than their exposure to $\mathrm{H}_{2} \mathrm{O}_{2}$ (for reviews see references 8 and 9). We examined the effects of neutrophils on

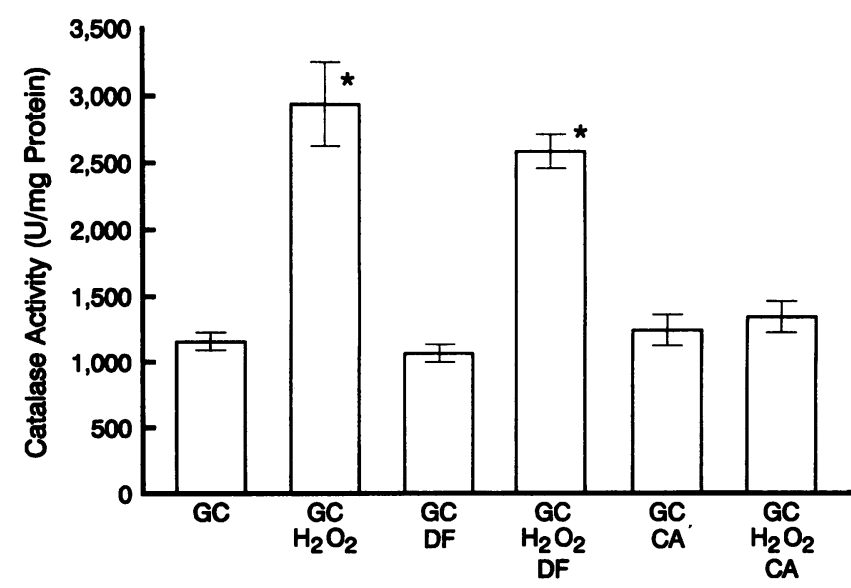

Figure 3. The effect of antioxidants and protein inhibition on gonococcal catalase response to $1.0 \mathrm{mM} \mathrm{H}_{2} \mathrm{O}_{2}$. Gonococci were exposed to $1.0 \mathrm{mM} \mathrm{H}_{2} \mathrm{O}_{2}$ in the presence of $0.2 \mathrm{mM}$ desferrioxamine $(D F)$ to chelate iron or $100 \mu \mathrm{g} / \mathrm{ml}$ chloramphenicol $(C A)$ to prevent new protein formation. Results represent the mean and SEM of three to eight separate experiments, each in duplicate. ${ }^{*}$ Differences $(P$ $<0.001$ ) between control bacteria and those treated with antioxidants. 


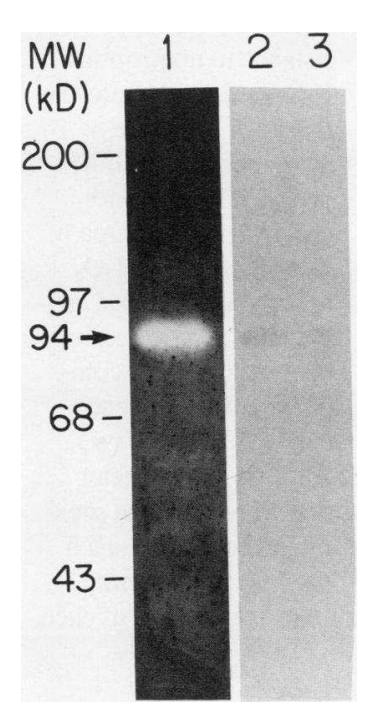

Figure 4. Immunoblotting of gonococcal cytoplasmic proteins before and after exposure to $\mathrm{H}_{2} \mathrm{O}_{2} .2 .0 \times 10^{9}$ gonococci were exposed to $1.0 \mathrm{mM}$ $\mathrm{H}_{2} \mathrm{O}_{2}$ as described in Fig. 1. The migration of partially purified gonococcal catalase $(5 \mu \mathrm{g})$ on an SDS-PAGE gel and stained for activity is shown in the first lane. Gonococcal cytoplasmic proteins $(100 \mu \mathrm{g})$ were run under identical conditions, transferred to nitrocellulose, and reacted with a rabbit polyclonal antibody raised against gonococcal catalase (see Methods). Gonococci exposed to $\mathrm{H}_{2} \mathrm{O}_{2}$ (lane 2) were compared with control bacteria (lane 3). Results are typical of two separate experiments. Exposure of gonococci to $\mathrm{H}_{2} \mathrm{O}_{2}$ caused a two- to threefold increase in the immunoreactive protein.

gonococcal expression of catalase. As shown in Fig. 5, neutrophil catalase can be distinguished from gonococcal catalase by native gel electrophoresis because of the difference in the size of these enzymes. We demonstrated that neutrophil and gonococcal catalase could be separated by brief sonication of the preparation and extensive washing (Fig. 5). This procedure was routinely used as a control to assure measurement of gonococcal (and not neutrophil) catalase activity.

Exposure of gonococci to neutrophils in the presence of PMA (to stimulate maximal secretion of $\mathrm{H}_{2} \mathrm{O}_{2}$; reference 29) led to a twofold increase in gonococcal catalase activity (Fig. 6 ). Experiments were conducted to determine the mechanisms

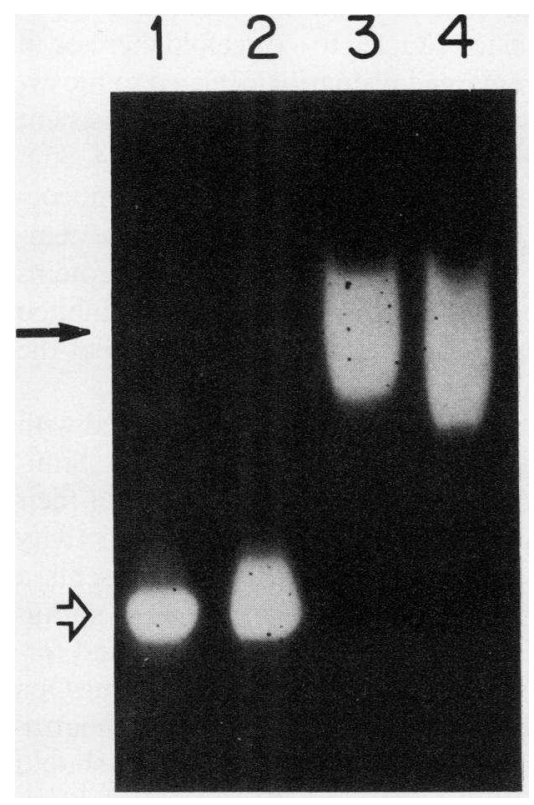

Figure 5. Native electrophoresis gel stained for catalase activity. Lane $l$ ( $5 \mu \mathrm{g}$ protein) contains gonococcal cytoplasmic proteins. Lane 2 ( $5 \mu$ g protein) contains $10^{8}$ gonococci exposed to an equal number of neutrophils stimulated with PMA $(100 \mathrm{ng} / \mathrm{ml})$. These samples were subjected to sonication $(20 \mathrm{~s}$, setting 60; Sonic Dismembrator Model 300; Fischer) centrifugation (2000 rpm, $20 \mathrm{~min}$ ), and were washed three times with PBS to remove neutrophil proteins before generating gonococcal cytoplasmic proteins. Lanes 3 and

$4\left(10 \mu \mathrm{g}\right.$ protein) contain $10^{8}$ neutrophils, and $100 \mathrm{ng} / \mathrm{ml}$ PMA was added to the cells in lane 4 . These preparations were used as a control for experiments to determine the effect of neutrophils on gonococcal catalase activity. The results are typical of eight separate experiments.

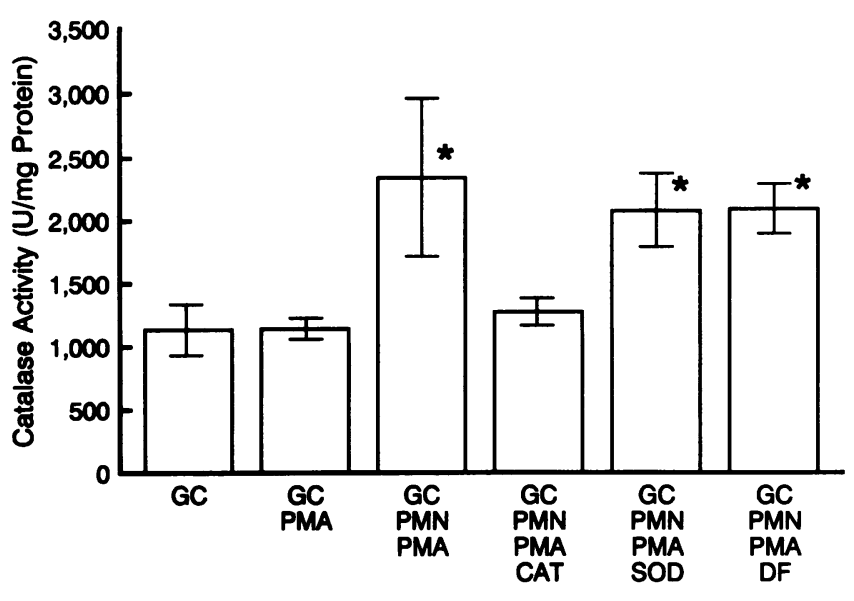

Figure 6. The effects of antioxidants and protein inhibition on response of gonococcal catalase to neutrophils. $10^{8}$ gonococci were incubated with an equal number of neutrophils for $1 \mathrm{~h}$. The effects of desferrioxamine $(D F ; 0.2 \mathrm{mM})$, catalase $(C A T ; 10 \mu \mathrm{g} / \mathrm{ml})$, and superoxide dismutase ( $S O D ; 10 \mu \mathrm{g} / \mathrm{ml}$ ) were examined. Results represent the mean and SEM of three to eight separate experiments, each in duplicate. *Significance differences $(P<0.01)$ between treated and control organisms.

for increased catalase activity, which might include stimulation by reactive oxygen species ( 9 ) and/or one or more microbicidal proteins (10). To dissect these possibilities gonococci were exposed to stimulated neutrophils in the presence of exogenous catalase and SOD, or the iron chelator desferrioxamine (Fig. 6 ). Only exogenous catalase prevented an increase in gonococcal catalase activity.

PMA was used in these experiments because it has been reported that only some variants of gonococci stimulate the release of reactive oxygen species by neutrophils $(4$, for review see reference 8). In particular, such stimulation has been related to expression of one or more heat modifiable Opa(PII) outer membrane proteins $(4,5,8)$. To further examine the effects of neutrophils on gonococci, we used gonococcal strain FA 1090 expressing Opa proteins $a$ and $b$, and a variant expressing no Opa proteins; these proteins were identified through the use of monoclonal antibodies as previously described (30). Organisms forming pili were used since pili are required to produce disease in vivo (31). Gonococci expressing Opa proteins were killed significantly better than variant bacteria failing to express Opa proteins ( Table II). The effect of exposure of gonococci to neutrophils with different Opa phenotypes is shown in Table II. Opa a and b organisms exposed to neutrophils demonstrated a 1.4- and 2-fold increase in catalase activity, respectively. Neutrophil exposure did not lead to stimulation of catalase in Opa-gonococci.

Experiments were conducted to determine whether an increase in gonococcal catalase activity could provide resistance to $\mathrm{H}_{2} \mathrm{O}_{2}$. As shown in Fig. 7, gonococci exposed to $1.0 \mathrm{mM}$ $\mathrm{H}_{2} \mathrm{O}_{2}$ demonstrated significant resistance at higher concentrations of $\mathrm{H}_{2} \mathrm{O}_{2}$. Experiments were conducted to determine whether exposure of gonococci to $\mathrm{H}_{2} \mathrm{O}_{2}$ also lead to increased resistance to neutrophils. Piliated Opa a gonococci were used, since they demonstrated the greatest sensitivity to neutrophils (Table II). As shown in Fig. 8, Opa a gonococci pretreated with $\mathrm{H}_{2} \mathrm{O}_{2}$ were significantly more resistant to neutrophils than control bacteria. 
Table II. Effect of Exposure to Neutrophils on Gonococcal Catalase

\begin{tabular}{ccc}
\hline Gonococcal phenotype & Catalase & Survival \\
\hline & U/mg protein & $\%$ \\
Opa- & $796.0 \pm 13.5$ & \\
+PMNs & $847.6 \pm 49.9$ & $90.3 \% \pm 8.5$ \\
Opa a & $845.1 \pm 20.8$ & \\
+PMNs & $1145.2 \pm 32.6^{*}$ & $54.7 \% \pm 8.0^{*}$ \\
Opa b & $793.7 \pm 22.2$ & \\
+PMNs & $1628.8 \pm 31.5^{*}$ & $76.7 \% \pm 7.2$ \\
& &
\end{tabular}

Results demonstrate the effects of interaction of neutrophils (PMNs) with gonococci of different Opa phenotype $(4,5,26)$ as well as bacterial survival after $60 \mathrm{~min}$ of phagocyte killing. Results are the mean and SEM of four separate experiments, each in duplication. ${ }^{*}$ Significant differences $(P<0.01)$ between control gonococci and those exposed to PMNs.

\section{Discussion}

Formation of reactive oxygen intermediates by phagocytic cells is one of several mechanisms that lead to the death of many microbes $(8,12,32)$. The importance of these reactive oxygen intermediates depends heavily on the microenvironmental conditions (9) and bacterial antioxidant defenses (12). Earlier studies with Staphylococcus aureus (33) and other organisms (for review see reference 12) have demonstrated that bacteria with high levels of catalase activity are more resistant to phagocytes than organisms with less catalase. However, in these studies the catalase activity of surviving organisms was not investigated.

At least some gonococcal strains stimulate formation of reactive oxygen intermediate by neutrophils $(4$, for review see

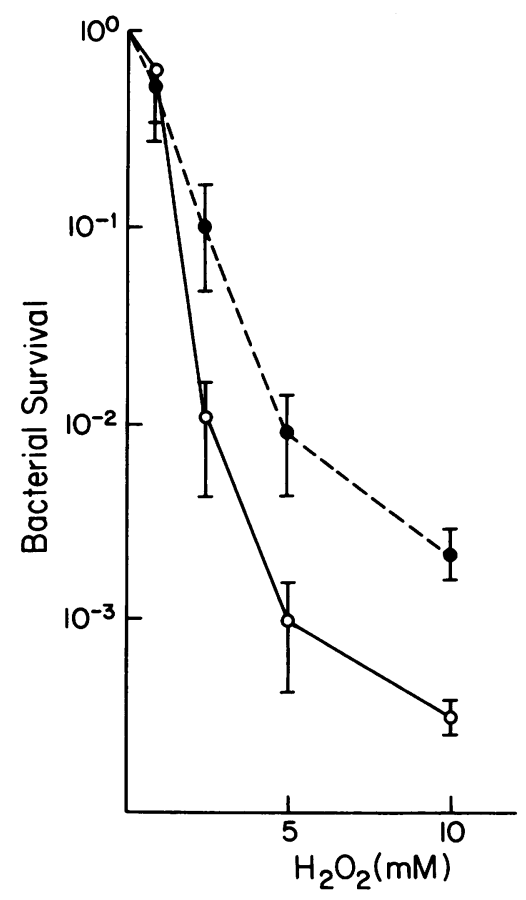

Figure 7. Effect of stress on gonococcal resistance to $\mathrm{H}_{2} \mathrm{O}_{2} .2 .0$ $\times 10^{9}$ gonococci pretreated with $1.0 \mathrm{mM}$ $\mathrm{H}_{2} \mathrm{O}_{2}$ as described for Fig. $1(\bullet)$ were challenged with higher concentrations of $\mathrm{H}_{2} \mathrm{O}_{2}$ for 60 min. Control organisms are shown with open circles. Results represent the mean and SD of four separate experiments, each in duplicate. Control organisms were significantly $(P<0.05)$ more susceptible to $\mathrm{H}_{2} \mathrm{O}_{2}$ than stressed bacteria at all $\mathrm{H}_{2} \mathrm{O}_{2}$ concentrations $>1.0 \mathrm{mM}$. Survival of stressed and control gonococci exposed to $1.0 \mathrm{mM} \mathrm{H}_{2} \mathrm{O}_{2}$ was not significantly different than for untreated organisms $\left(0 \mathrm{mM} \mathrm{H}_{2} \mathrm{O}_{2}\right)$.

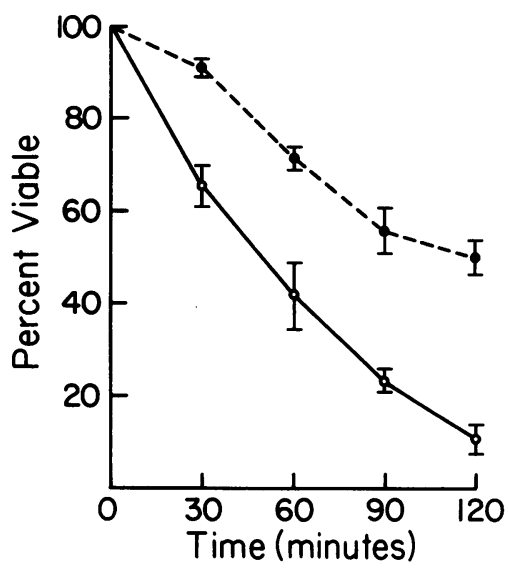

Figure 8. Effect of $\mathrm{H}_{2} \mathrm{O}_{2}$ stress on gonococcal resistance to neutrophils. Results demonstrate the effects of exposure of gonococci to $1.0 \mathrm{mM}$ $\mathrm{H}_{2} \mathrm{O}_{2}$. Piliated gonococci expressing Opa a were exposed to $\mathrm{H}_{2} \mathrm{O}_{2}$ exactly as described in Fig. 1. Killing of control bacteria $(0)$ were compared with gonococci exposed to $\mathrm{H}_{2} \mathrm{O}_{2}(\bullet)$. Results are the mean and SEM of three separate experiments, each

in duplicate. Opa a gonococci exposed to $\mathrm{H}_{2} \mathrm{O}_{2}$ were significantly more resistant to neutrophils $(P<0.05)$ than control bacteria at each time point examined.

reference 8). Gonococci make no SOD (13-15), and it has been proposed that catalase, which is expressed in high concentration in gonococci relative to some other human pathogens (16), helps to offset this deficiency (14). We examined catalase activity with the belief that this enzyme might play a role in protection of gonococci from neutrophils. Since gonococci do not appear to be killed effectively by neutrophils in vivo, the dynamic response of catalase activity was of particular interest.

Gonococcal catalase was primarily localized to the cytoplasm. A small concentration of the enzyme was found in the cytoplasmic membrane. This could represent contamination during the fractionation procedure, but the cytoplasmic enzyme G-6PDH was not found in gonococcal cytoplasmic membranes prepared under identical conditions. In $E$. coli, different isoenzymes of catalase are found in the cytoplasm and periplasmic space (34). We observed only a single form of gonococcal catalase in the cellular fractions prepared.

Exposure of gonococci to $\mathrm{H}_{2} \mathrm{O}_{2}$ led to a threefold increase in enzyme activity, which remained primarily localized to the cytoplasmic compartment. This increase in catalase is consistent with that observed in other bacteria exposed to $\mathrm{H}_{2} \mathrm{O}_{2}(34,35)$. Neither paraquat nor heat shock caused an increase in gonococcal catalase expression. Greenberg and Demple (36) have demonstrated that paraquat causes formation of $E$. coli proteins distinct from other forms of stress. Paraquat actually inhibited gonococcal catalase activity, consistent with the idea that the superoxide generated could inactivate catalase (37).

Gonococci exposed to human neutrophils stimulated with PMA also demonstrated an increase in catalase activity. Similar results were obtained using Opa variants differing in their interaction with neutrophils. The increase in catalase activity observed in gonococci attacked by neutrophils represents a complex balance between the ability of these bacteria to stimulate neutrophil formation of $\mathrm{H}_{2} \mathrm{O}_{2}$ and their survival and formation of adaptive stress proteins. It is believed that some Opa proteins facilitate binding and ingestion of gonococci by neutrophils $(4,38)$, and our results support this hypothesis. It should be noted that neutrophil killing of gonococci observed represents the composite of intracellular and extracellular killing. Catalase activity was greater in Opa b than Opa a gonococci exposed to neutrophils, presumably reflecting the poor survival of the latter gonococcal phenotype. Catalase did not increase in 
Opa-gonococci, likely because of limited stimulation of neutrophil oxidative metabolism. Neutrophil killing of Opa variants a and $b$ was the opposite of that reported by Rest and coworkers $(4,38)$. However, piliated organisms were not used in the latter studies. Additional experiments demonstrated that exogenous catalase, but not other antioxidants, blocked the increase in gonococcal catalase produced by neutrophils. In addition, the increase in catalase activity observed could be ascribed to new protein formation.

Gonococci exposed to $\mathrm{H}_{2} \mathrm{O}_{2}$ demonstrated significant resistance to neutrophil killing and higher concentrations of $\mathrm{H}_{2} \mathrm{O}_{2}$. Such resistance seems most likely due to increased formation of catalase. This relationship could be confirmed through use of a catalase-deficient isogenic mutant. However, the gene for gonococcal catalase has not been cloned. A wild-type gonococcal strain deficient in catalase was identified at the Center for Disease Control. This isolate is more sensitive to $\mathrm{H}_{2} \mathrm{O}_{2}$ and neutrophils than other gonococcal strains we have examined ( unpublished data and personal communication, Steven Johnson, Centers for Disease Control), and does not develop characteristic changes we have described for gonococcal strain FA1090 after exposure to $\mathrm{H}_{2} \mathrm{O}_{2}$.

We believe the results of the work presented have two important implications. First, they emphasize the dynamic nature of catalase in gonococci and perhaps other bacteria as well. Brief exposure of these bacteria to $\mathrm{H}_{2} \mathrm{O}_{2}$ or neutrophils permits an increase in catalase activity. Experiments designed to examine the relationship of catalase to phagocyte microbicidal effects should take into consideration this stress response.

Second, this physiological response lends itself to discussion of the overall interaction of gonococci with neutrophilic phagocytes. This and other studies must explain the mechanism(s) by which gonococci survive in vivo (for review see references 8 and 39). Studies with antibodies obtained from hosts with gonococcal urethritis and pelvic inflammatory disease suggest gonococci make unique proteins resulting from both aerobic and anaerobic conditions in vivo (40). Gonococci most likely function in both aerobic and anaerobic environments $(39,41)$. We believe that the early interactions between neutrophils and gonococci at the mucosal surface are likely to involve oxidant stress, whereas subsequent interactions may be anaerobic, at least in part due to gonococcal competition for molecular oxygen $(7,41)$. The anaerobic killing of gonococci has been emphasized because of sensitivity of the organism to cells harvested from patients with chronic granulomatous disease (reference 38; which cannot make $\mathrm{H}_{2} \mathrm{O}_{2}$ ) and to normal neutrophils under anaerobic conditions (42). However, the general sensitivity of gonococci to oxidants $(16,43$, $44)$ and the increased sensitivity of a catalase-deficient wildtype gonococcal isolate to neutrophils (unpublished data) requires reconsideration of the relative importance of $\mathrm{O}_{2}$-dependent and $\mathrm{O}_{2}$-independent neutrophil killing. The natural history of gonococcal disease requires that we explain survival of the organism under both aerobic and anaerobic conditions. By providing increased resistance to $\mathrm{H}_{2} \mathrm{O}_{2}$, catalase could allow gonococci to survive at least one aspect of the neutrophil attack.

\section{Acknowledgments}

The authors thank Dr. Janne Cannon, Steven Johnson, and Tim Alcorn for review of this manuscript, and Ms. Desiree Bright, Paula Warren, and Elizabeth Mikulski for secretarial help.
This work was supported by National Institutes of Health grants U01-A131496, RO1-AI92939, and PO-1AI7001.

\section{References}

1. Britigan, B. E., M. S. Cohen, and P. F. Sparling. 1985. Gonococcal infection: a model of molecular pathogenesis. N. Engl. J. Med. 312:1683-1694.

2. Densen, P., L. A. MacKeen, and R. A. Clark. 1982. Dissemination of gonococcal infection is associated with delayed stimulation of complement-dependent neutrophil chemotaxis in vitro. Infect. Immun. 38:563-572.

3. Parsons, N. J., A. A. Kawaasi, J. A. Turner, D. R. Veale, V. Y. Perera, C. W. Penn, and H. Smith. 1981. Investigation of the determinants of the survival of Neisseria gonorrhoeae within human polymorphonuclear phagocytes. J. Gen. Microbiol. 127:103-112.

4. Fischer, S. H., and R. F. Rest. 1988. Gonococci possessing only certain P.II outer membrane proteins interact with human neutrophils. Infect. Immun. 56:1574-1579.

5. Virji, M., and J. E. Heckels. 1986. The effect of protein II and pili on the interaction of Neisseria gonorrhoeae with human polymorphonuclear leucocytes. J. Gen. Microbiol. 132:503-512.

6. Rosenthal, R. S., R. S. Fulbright, M. E. Eads, and W. D. Sawyer. 1977. Ethylenediaminetetraacetic acid-sensitive antiphagocytic activity of Neisseria gonorrhoeae. Infect. Immun. 15:817-827.

7. Britigan, B. E., and M.S. Cohen. 1986. Effects of human serum on bacterial competition with neutrophils for molecular oxygen. Infect. Immun. 52:657-663.

8. Shafer, W. M., and R. F. Rest. 1989. Interactions of gonococci with phagocytic cells. Annu. Rev. Microbiol. 43:121-145.

9. Hassett, D. J., and M. S. Cohen. 1989. Bacterial adaptation to oxidative stress: implications for pathogenesis and interaction with phagocytic cells. $F A$ SEB (Fed. Am. Soc. Exp. Biol.) J. 3:2574-2582.

10. Spitznagel, J. K. 1990. Antibiotic proteins of human neutrophils. J. Clin. Invest. 86:1381-1386.

11. Clark, R. A. 1990. The human neutrophil respiratory burst oxidase. $J$. Infect. Dis. 161:1140-1147.

12. Beaman, L., and B. L. Beaman. 1984. The role of oxygen and its derivatives in microbial pathogenesis and host defense. Annu. Rev. Microbiol. 38:2748.

13. Norrod, P., and S. A. Morse. 1979. Absence of superoxide dismutase in some strains of Neisseria gonorrhoeae. Biochem. Biophys. Res. Commun. 90:1287-1294.

14. Archibald, F. S., and M. Duong. 1986. Superoxide dismutase and oxygen toxicity defenses in the genus Neisseria. Infect. Immun. 51:631-634.

15. Cohen, M. S., Y. Chai, B. E. Britigan, W. McKenna, J. Adams, T. Svendsen, K. Bean, D. J. Hassett, and P. F. Sparling. 1987. Role of extracellular iron in the action of the quinone antibiotic streptonigrin: mechanisms of killing and resistance of Neisseria gonorrhoeae. Antimicrob. Agents Chemother. 31:15071513.

16. Hassett, D. J., L. Charniga, and M. S. Cohen. 1990. recA and catalase in $\mathrm{H}_{2} \mathrm{O}_{2}$-mediated toxicity in Neisseria gonorrhoeae. J. Bacteriol. 172:7293-7296.

17. Klimpel, K. W., and V. L. Clark. 1988. The heat shock response of type 1 and type 4 gonococci. Sex. Transm. Dis. 141-147.

18. Beers, R. F., and I. W. Sizer. 1952. A spectrophotometric method for measuring the breakdown of hydrogen peroxide by catalase. J. Biol. Chem. 195:133-140.

19. Bradford, M. M. 1976. A rapid and sensitive method for the quantification of microgram quantities of protein utilizing the principle of protein-dye binding Anal. Biochem. 72:248-254.

20. Clare, D. A., M.-N. Duong, D. Darr, F. S. Archibald, and I. Fridovich. 1984. Effect of molecular oxygen on detection of superoxide radical with nitroblue tetrazolium and on activity stains for catalase. Anal. Biochem. 140:532-537.

21. Noltman, E. A., C. I. Gubler, and S. A. Kuby. 1961. Glucose-6-phosphate dehydrogenase. I. Isolation of the crystalline enzyme from yeast. J. Biol. Chem. 236:1225-1230.

22. Sambrook, J., E. F. Fritsch, and T. Maniatis. 1989. Molecular Cloning: A Laboratory Manual. Cold Spring Harbor Laboratory Press, Cold Spring Harbor, NY.

23. Teerlink, T., H. Versantvoort, and E. C. Beurery. 1987. Antigenic and immunogenic properties of cyanogen bromide peptides from gonococcal oute membrane protein IB. Evidence for the existance of a surface-exposed conserved epitope. J. Exp. Med. 166:63-76.

24. Burnette, W. N. 1981. "Western blotting": electrophoretic transfer of proteins from sodium dodecyl sulfate-polya-crylamide gets to unmodified nitrocellulose and radiographic detection with antibody and radioiodinated protein $A$. Anal. Biochem. 112:195-203.

25. Amersham International. Western Blotting Technical Manual. 1991.

26. Hassett, D. J., B. E. Britigan, T. Svendsen, G. M. Rosen, and M. S. Cohen 1987. Bacteria form intracellular free radicals in response to paraquat and streptonigrin: demonstration of the potency of hydroxyl radical. J. Biol. Chem 262:13404-13408. 
27. Woods, M. L. R., Z. A. Bonfiglioli, Z. A. McGee, and C. Georgopoulos. 1990. Synthesis of a select group of proteins by Neisseria gonorrhoeae in response to thermal stress. Infect. Immun. 58:719-725.

28. Fu, K.-S., D. J. Hassett, and M. S. Cohen. 1989. Oxidant stress in Neisseria gonorrhoeae: adaptation and effects on $\mathrm{L}-(+)$-lactate dehydrogenase. In fect. Immun. 57:2173-2178.

29. DeChatelet, L. R., P. S. Shirley, and R. B. Johnston, Jr. 1976. Effect of phorbol myristate acetate on the oxidative metabolism of human polymorphonuclear leukocytes. Blood. 47:545-554.

30. Black, W. J., R. S. Schwalbe, I. Nachamkin, and J. G. Cannon. 1984. Characterization of Neisseria gonorrhoeae protein II phase variation by use of monoclonal antibodies. Infect. Immun. 45:453-457.

31. Kellogg, Jr., D. S., I. R. Cohen, L. C. Norins, A. L. Schroeter, and G. Reising. 1968. Neisseria gonorrhoeae. Colonial variation and pathogenicity during 35 months in vitro. J. Bacteriol. 96:596-605.

32. Root, R. K., and M. S. Cohen. 1981. The microbicidal mechanisms of human neutrophils and eosinophils. Rev. Infect. Dis. 3:565-598.

33. Mandell, G. L. 1975. Catalase, superoxide dismutase, and virulence of Staphylococcus aureus, in vitro and in vivo studies with emphasis on staphylococcal-leukocyte interaction. J. Clin. Invest. 55:561-566.

34. Loewen, P. C., J. Switala, and B. L. Triggs-Raine. 1985. Catalases HPI and HPII in Escherichia coli are induced independently. Arch. Biochem. Biophys. 243:144-149.

35. Finn, G. J., and S. Condon. 1975. Regulation of catalase synthesis in Salmonella typhimurium. J. Bacteriol. 123:570-579.

36. Greenberg, J. T., and B. Demple. 1989. A global response induced in
Escherichia coli by redox-cycling agents overlaps with that induced by peroxide stress. J. Bacteriol. 171:3933-3939.

37. Kono, Y., and I. Fridovich. 1982. Superoxide radical inhibits catalase. $J$. Biol. Chem. 257:5751-5754.

38. Rest, R. F., S. H. Fischer, Z. Ingham, and J. F. Jones. 1982. Interactions of Neisseria gonorrhoeae with human neutrophils: effects of serum and gonococcal opacity on killing and chemiluminescence. Infect. Immun. 36:737-744.

39. Cohen, M. S., and P. F. Sparling. 1992. Mucosal infection with Neisseria gonorrhoea. Bacterial adaptation and mucosal defenses. J. Clin. Invest. 89:16991705.

40. Clark, V. L., J. S. Knapp, S. Thompson, and K. W. Klimpel. 1988. Presence of antibiotics to the major anaerobically induced gonococcal outer membrane protein in sera from patients with gonococcal infections. Microb. Pathog. 5:381-390.

41. Cohen, M. S., and B. E. Britigan. 1988. An expanded view of the phagocytic respiratory burst: bacterial competition for oxygen and its stimulation by host factors. In The Respiratory Burst and Its Physiological Significance. A. J. Sbarra and R. R. Strauss, editors. Plenum, New York. 99-116.37.

42. Casey, S. G., W. M. Shafer, and J. K. Spitznagel. 1986. Neisseria gonorrhoeae survives intraleukocytic oxygen-independent antimicrobial capacities of anaerobic and aerobic granulocytes in the presence of pyocin lethal for extracellular gonococci. Infect. Immun. 52:834-889.

43. Ismail, G., W. D. Sawyer, and W. S. Wegener. 1977. Effect of hydrogen peroxide and superoxide radical on viability of Neisseria gonorrhoeae and related bacteria. Proc. Soc. Exp. Biol. Med. 155:264-269.

44. Rest, R. F. 1979. Killing of Neisseria gonorrhoeae by human polymorphonuclear granule extracts. Infect. Immun. 25:574-579. 